\title{
Isomerization of 2,4-Diphenyl-1-butene over Silica-Alumina Catalysts
}

\author{
Taichi OgawA*, Takashi Sawagughi*, Takeshi Kuroki* and Tadashi Ikemura*
}

The catalytic isomerization of 2,4-diphenyl-1-butene over two kinds of silica-alumina catalysts (IS and Neobead-P) was carried out at $300^{\circ} \mathrm{C}$ in the range of $0.1 \times 10^{4} \sim 40 \times 10^{4}$ g-catalyst $\cdot$ sec/g-mol-feed using a fixed bed flow reactor system.

The main products formed over the two catalysts were different; 1-methyl-1-phenylindan and 1,3-diphenyl-2-butenes were the main products over the IS catalyst while 1,3-diphenyl2-butenes were the main products over the Neobead-P catalyst. It was found that these products were formed by catalytic isomerization reactions of 2,4-diphenyl-1-butene (D.P.B.E). One of the reactions was isomerization of D.P.B.E to 1-methyl-1-phenylindan which occurred only over the IS catalyst, and the other was double-bond isomerization of D.P.B.E which occurred over both the IS and Neobead-P catalysts.

The experimental results were interpreted to be attributable to the differences in the acidic properties of the catalysts. In particular, it was found that strong acid sites of $\mathrm{H}_{0}<+1.5$ promoted the formation of 1-methyl-1-phenylindan.

\section{Introduction}

Although the recovery of fuel oils by pyrolysis of polymers has been dealt with as an effective technique for efficient utilization of plastic wastes $^{1) ~ 3)}$, the techniques themselves have not been studied sufficiently. As one of the other approaches for reuse of plastic wastes, the direct use of liquid products obtained from pyrolysis of plastic wastes would seem more relevant. In general, the composition of industrial plastic wastes is simpler in comparison with that of municipal wastes ${ }^{2), 4)}$ Consequently, the liquid products obtained from pyrolysis of industrial plastic wastes would be of simpler composition. The authors have shown that the products obtained from pyrolysis of polystyrene consisted of monomer (styrene), dimer (2,4-diphenyl-1-butene), trimer (2,4,6-triphenyl-1-hexene) and trace quantities of heavy oily products $(4 \sim 10$ monomer units $)^{5), 6)}$. Since the products are a mixture of $\alpha$-olefins, they could be converted conveniently to useful compounds. For example, dimerization of styrene to cyclic dimer (1-methyl-3-phenylindan) with various acid catalysts has been reported ${ }^{7) ~ 9)}$. In the dimerization of styrene, it is expected that a linear dimer, 1,3-diphenyl-1-butene, would be present as an intermediate. Although the reaction mechanism has not been elucidated, such cyclic dimers as 1-methyl-3-phenylindan are import-

Received May 2, 1980.

* Department of Industrial Chemistry, College of Science and Technology, Nihon University (1-5, Kanda Surugadai, Chiyoda-ku, Tokyo 101) ant materials for synthetic lubricating oils ${ }^{10}$. If catalytic isomerization of 2,4-diphenyl-1-butene (D.P.B.E) is promoted by solid acid catalysts, formations of cyclic compounds could be expected.

On the other hand, only a few reports on the synthesis of D.P.B.E'11) are available, moreover, its chemical reactions are not detailed sufficiently. The authors have already reported about the thermal decomposition of D.P.B.E $\left.{ }^{12}\right)$ in connection with the elucidation of its chemical reaction characteristics.

In the present study, an attempt has been made to obtain 1-methyl-1-phenylindan from D.P.B.E using silica-alumina catalysts, and to discuss about the reaction mechanism of catalytic isomerization based on the results obtained.

\section{Experimental}

\subsection{Materials}

2,4-Diphenyl-1-butene (D.P.B.E) was prepared by thermal decomposition of polystyrene carried out at $370^{\circ} \mathrm{G}$ in a flow reactor ${ }^{5}$. The decomposition products were distilled to obtain a styrene dimer fraction (b.p. $140 \sim 145^{\circ} / 4 \mathrm{~mm} \mathrm{Hg}$ ). This styrene dimer fraction was recrystallized five times from its ethyl alcohol solution cooled in a dry ice-methanol bath.

The purity of D.P.B.E determined by GG was over $98.5 \%$. The impurities found in D.P.B.E were 1,3-diphenyl-2-butene and 1,3-diphenylpropane.

\subsection{Catalysts}

Two silica-alumina catalysts were used in the 
Table 1 Indicators Employed in Titration of Suspension in Benzene with $n$-Butylamine

\begin{tabular}{ll}
\hline \multicolumn{1}{c}{ Indicators } & $\mathrm{pKa}$ \\
\hline Neutral red & +6.8 \\
$p$-Dimethylaminoazobenzene & +3.3 \\
Benzeneazodiphenylamine & +1.5 \\
Benzalacetophenone & -5.6 \\
Antraquione & -8.2 \\
\hline
\end{tabular}

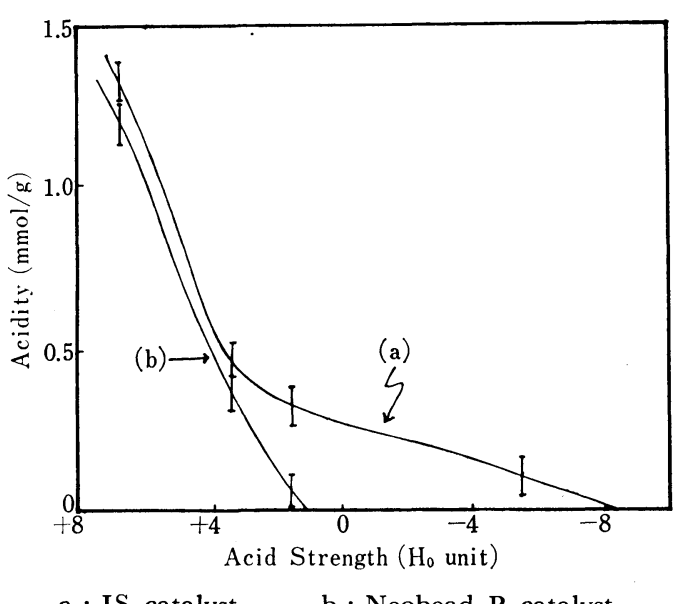

$$
a: \text { IS catalyst } \quad b: \text { Neobead-P catalyst }
$$

Fig. 1 Acid Strength Distributions of Silica-Alumina Catalysts

present work. One of them was IS catalyst containing $13 \mathrm{wt} \%$ alumina supplied by Catalysts and Chemicals IND. Co. The other was Neobead-P containing $88 \mathrm{wt} \%$ alumina supplied by Mizusawa Chemical Co.

Both catalysts were crushed to $20 \sim 40$ mesh size particles and calcinated in a stream of air at $540^{\circ} \mathrm{C}$ for $3 \mathrm{hr}$ before use.

Acidity was measured by titrating the catalyst suspended in benzene with $n$-buthylamine ${ }^{13)}$ using the indicators shown in Table 1. The results of titration are shown in Fig. 1. The IS catalyst had a broad distribution of acid strengths, but Neobead-P catalyst had only acid sites of $\mathrm{H}_{0}>$ +1.5 .

\subsection{Apparatus}

All experiments were carried out using the same type of reactor reported previously ${ }^{12}$ ). The reactor comprised a preheater section and a catalyst-packed reactor section made of a quartz tubing $500 \mathrm{~mm}$ in length and $14 \mathrm{~mm}$ in diameter. The reactor was heated with five electric furnaces controlling its temperature within $\pm 2{ }^{\circ} \mathrm{C}$.

A nitrogen stream precisely controlled by a flow meter was used as a diluent or carrier gas. Liquid D.P.B.E was introduced into the preheater section with a volumetric micro feeder, and the gas mixture of nitrogen and the vaporized D.P.B.E passed through the reactor. The reaction conditions employed in the present work were as follows: reaction temperature, $300^{\circ} \mathrm{C}$; contact time, $0.1 \times 10^{4} \sim 40 \times$ $10^{4}$ (g-catalyst $\times$ sec/g-mol-feed); process time, 19 min; and the molar ratio of nitrogen to D.P.B.E, 18.

Liquid products at room temperature were collected in a methanol-dry ice trap located just below the reactor, and gaseous products were collected in a gas holder. The percentage of material balance obtained in all experiments was about 98 .

\subsection{Analysis}

Instruments used for identifying the products were the same as those used in a previous work ${ }^{12}$.

Shimazu GC-6A gas chromatograph was used for separation of liquid products. Separation was effected by use of the column $(3 \mathrm{~mm} \phi \times 3,000 \mathrm{~mm})$ of $15 \%$ Apiezon grease L supported on Chromosorb WAW (60 80 mesh).

Gaseous products at room temperature were analyzed by Shimazu 4B-PT gas chromatograph, and it was observed that the amount of gaseous products was less than $0.5 \mathrm{wt} \%$ of the total products in which methane was the main product. Consequently, the gaseous products were not important in the study of the present work.

\section{Results and Discussion}

\subsection{Reaction Products}

Each product separated fractionally by GG was identified by the generally available instruments. The results obtained are shown as follows:

1) 1-Methylindan ${ }^{14)}$

${ }^{1} \mathrm{H}-\mathrm{NMR}\left(\delta_{\mathrm{ppm}}^{\mathrm{CDC1}}\right): 1.28\left(3 \mathrm{H}\right.$, doublet, $\left.\mathrm{CH}_{3}\right)$, $1.63(1 \mathrm{H}$, multiplet, $\mathrm{C}(\mathrm{H}) \mathrm{H}), 2.30$ ( $1 \mathrm{H}$, multiplet, $\mathrm{CH}(\mathrm{H})$ ), 2.87 (2H, multiplet, $\left.\mathrm{CH}_{2}\right), 3.18$ (1H, multiplet, $\mathrm{CH}), 7.17\left(4 \mathrm{H}\right.$, singlet, $\left.\mathrm{C}_{6} \mathrm{H}_{4}\right)$

The IR spectrum was identical with that of 1-methylindan ${ }^{15}$.

2) 3-Methylindene ${ }^{14)}$

${ }^{1} \mathrm{H}-\mathrm{NMR}\left(\delta_{\mathrm{ppm}}^{\mathrm{CDCl}_{3}}\right): 2.16(3 \mathrm{H}$, singlet, fine splitting), 3.30 (2H, singlet, fine splitting), $6.20(1 \mathrm{H}$, singlet, fine splitting), $7.07 \sim 7.48$ (4H, multiplet)

3) cis-1,3-Diphenyl-2-butene ${ }^{16), 17)}$

$\operatorname{MS}(\mathrm{m} / \mathrm{e}): \mathrm{M}^{+}=208$

${ }^{1} \mathrm{H}-\mathrm{NMR}\left(\delta_{\mathrm{ppm}}^{\mathrm{CDCl}}\right): 2.08$ (3H, singlet), $3.32(2 \mathrm{H}$, doublet), 5.65 (1H, triplet), $7.24(10 \mathrm{H})$

4) 1-Methyl-1-phenylindan

$\operatorname{MS}(\mathrm{m} / \mathrm{e}): \mathrm{M}^{+}=208$

${ }^{1} \mathrm{H}-\mathrm{NMR}\left(\delta_{\mathrm{ppm}}^{\mathrm{CDCl}_{3}}\right): 1.67$ (3H, singlet), $2.28(2 \mathrm{H}$, multiplet), 2.89 (2H, multiplet), $7.20(9 \mathrm{H})$ 
Table 2 Typical Data on Catalytic Isomerization of 2,4-Diphenyl-1-Butene over Silica-Alumina Catalysts Reaction Conditions (Temp. $300^{\circ} \mathrm{C}$; Process period $19 \min ; \mathrm{N}_{2} / \mathrm{sample}=18$ )

\begin{tabular}{|c|c|c|c|c|c|c|c|}
\hline \multirow{3}{*}{$\begin{array}{l}\text { Catalyst } \\
\text { Contact time } \\
\quad(g-\text { cat } \cdot \text { sec } / g-\text { mol-feed }) \\
\text { Conversion }(\%)\end{array}$} & \multicolumn{3}{|c|}{ IS-cat } & \multicolumn{3}{|c|}{ Neobead-P } & \multirow{3}{*}{$\begin{array}{c}5.2 \times 10^{4} \\
88.1\end{array}$} \\
\hline & $0.1 \times 10^{4}$ & $0.2 \times 10^{4}$ & $4.4 \times 10^{4}$ & $0.1 \times 10^{4}$ & $1.3 \times 10^{4}$ & $2.8 \times 10^{4}$ & \\
\hline & 49.7 & 58.5 & 96.8 & 19.3 & 56.2 & 84.8 & \\
\hline \multicolumn{8}{|l|}{$\begin{array}{l}\text { Products } \\
\text { (moles } / 100 \text { moles feed) }\end{array}$} \\
\hline Benzene & 0.4 & 0.4 & 11.5 & - & - & - & - \\
\hline Ethylbenzene & 0.1 & 0.3 & 2.6 & - & - & - & - \\
\hline Isopropylbenzene & 0.3 & 0.8 & 3.0 & - & - & - & - \\
\hline 1-Methylindan & 0.3 & 0.3 & 6.6 & - & - & - & - \\
\hline 3-Methylindene & 0.1 & 0.2 & 4.6 & - & - & - & - \\
\hline cis-1,3-Diphenyl-2-butene & 8.0 & 7.0 & 2.4 & 2.5 & 8.6 & 21.8 & 24.7 \\
\hline 1-Methyl-1-phenylindan & 14.8 & 22.8 & 68.7 & - & - & $\ldots$ & - \\
\hline 1,3-Diphenyl-1-butene & 1.1 & 1.3 & 1.3 & - & 2.4 & 6.3 & 7.6 \\
\hline trans-1,3-Diphenyl-2-butene & 15.6 & 14.3 & 3.4 & 5.2 & 28.8 & 40.7 & 40.4 \\
\hline High boiling-point products & 5.0 & 5.9 & 3.9 & 5.8 & 8.2 & 8.0 & 7.7 \\
\hline
\end{tabular}

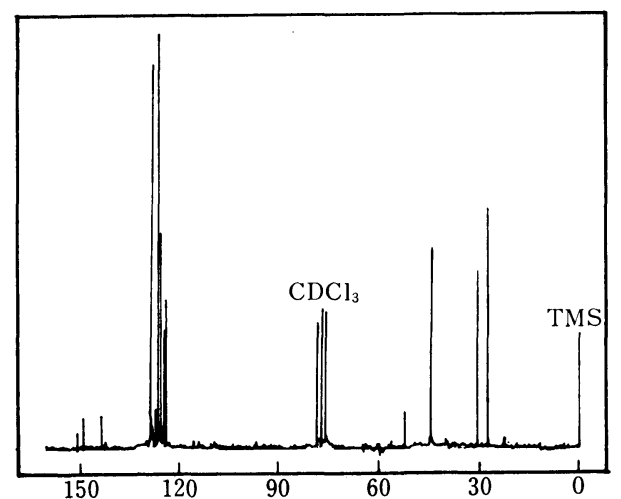

Fig. 2 13C NMR Spectrum of 1-Methyl-1-phenylindan in $\mathrm{CDCl}_{3}(25.05 \mathrm{MHz})$

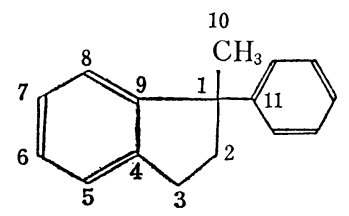

The ${ }^{13} \mathrm{G}$ NMR spectrum of 1-methyl-1-phenylindan is shown in Fig. 2. Each carbon peak is assigned on the basis of off-resonance decoupling results as follows: $\mathrm{G}(10),-\mathrm{CH}_{3}(27.5 \mathrm{ppm})$; $\mathrm{C}$ (2) and $\mathrm{C}$ (3), $-\mathrm{CH}_{2}-(30.5$ and $44.2 \mathrm{ppm})$; $\mathrm{C}$

(1) and $\mathrm{C}(4),(9),(11),-{ }_{\mathrm{I}}^{\mathrm{C}}-\mathrm{-}(52.1$ and 143.6, $149.0,150.9 \mathrm{ppm})$

5) trans-1,3-Diphenyl-1-butene ${ }^{18)}$

$\operatorname{MS}(\mathrm{m} / \mathrm{e}): \mathrm{M}^{+}=208$

${ }^{1} \mathrm{H}-\mathrm{NMR}\left(\delta_{\mathrm{ppm}}^{\mathrm{CDCl}_{3}}\right): 1.47$ (3H, singlet), $3.63(1 \mathrm{H}$, multiplet), 6.39 (2H, multiplet), $7.28(10 \mathrm{H}$, multiplet)

6) trans-1,3-Diphenyl-2-butene ${ }^{\mathbf{1 6}), 17)}$

MS (m/e): $\mathrm{M}^{+}=208$

${ }^{1} \mathrm{H}-\mathrm{NMR}\left(\delta_{\mathrm{ppm}}^{\mathrm{CDCl}_{3}}\right): 2.15$ (3H, singlet), $3.57(2 \mathrm{H}$, doublet), 5.97 (1H, triplet), $7.26(10 \mathrm{H})$

Table 2 shows some typical data on the catalytic isomerization of D.P.B.E over silica-alumina catalysts. The high boiling-point products shown in Table 2 represent the fractions undetected by GC.

Over the IS catalyst, 1-methyl-1-phenylindan and 1,3-diphenyl-2-butenes were the main reaction products, and some low boiling-point products such as benzene, 1-methylindan and 3-methylindene were also formed. However, over the Neobead-P catalyst, 1,3-diphenyl-2-butenes were the main products but no 1-methyl-1-phenylindan and low boiling-point products were formed. Further, it was ascertained in a separate work that the molecular weight of each of the main products formed over both catalysts was the same as that of D.P.B.E.

From the results described above, it was concluded that isomerization of D.P.B.E proceeded predominantly over the two catalysts. Over the Neobead-P catalyst, the sum of 1,3-diphenyl-2butenes formed was about $80 \mathrm{wt} \%$ of the liquid product in which 1,3-diphenyl-1-butene was $7 \mathrm{wt} \%$.

On the other hand, a large amount of 1-methyl1-phenylindan was formed over the IS catalyst. The yield of 1-methyl-1-phenylindan was about $80 \mathrm{wt} \%$ of the liquid products. Further, it was found from Table 2 that the yield of 1,3-diphenyl2-butenes over the IS catalyst was less than that over the Neobead-P catalyst over which no isomerization of D.P.B.E to 1-methyl-1-phenylindan took place. Differences in the results obtained over the two catalysts seem to result from such acidic properties of these catalysts as shown in Fig. 1.

The relationship between yield of each product and process time over the IS catalyst is shown in Fig. 3. The yield of 1-methyl-1-phenylindan increased rapidly to a constant level with increase in process time while the yield of benzene or the 


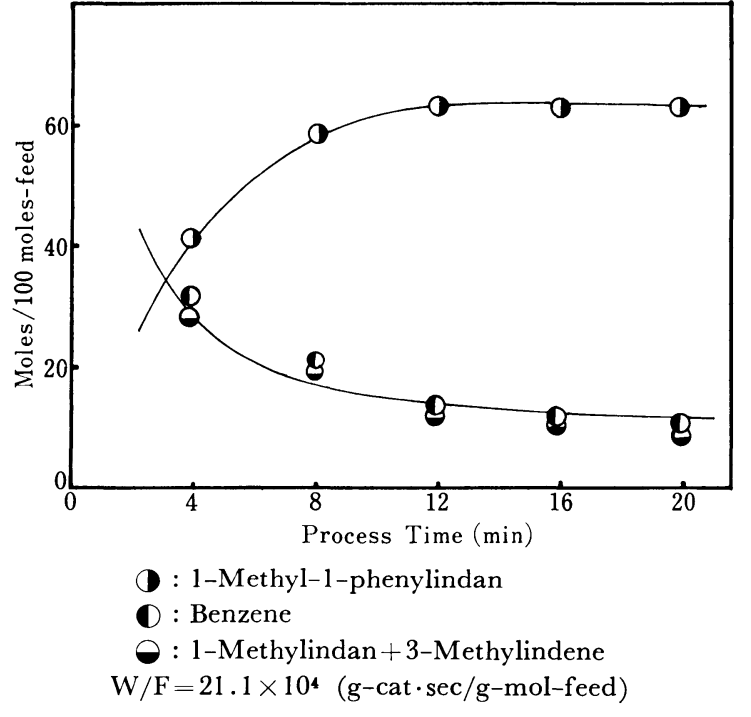

Fig. 3 Effect of Process Time on Yield of Each Product over IS Catalyst

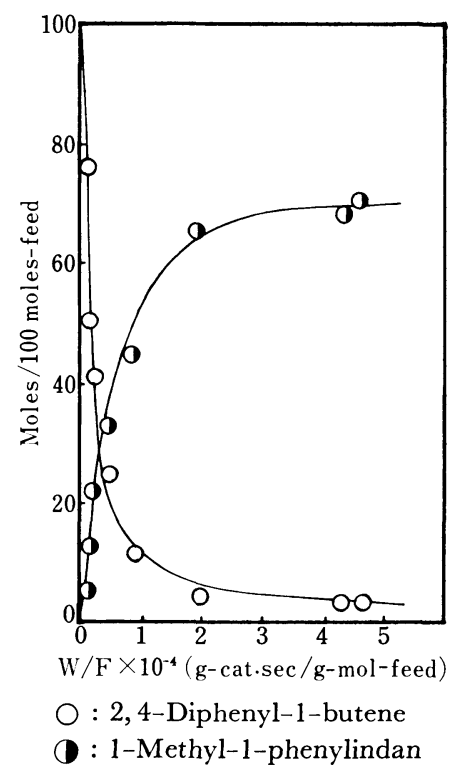

Fig. 4 Relationship between Yield of 1-Methyl-1phenylindan and Contact Time over IS Catalyst

sum of the yields of 1-methylindan and 3-methylindene decreased. The yield of each product remained constant after about 10 minutes.

It is well known that the activity of catalysts decreases with increase in process time ${ }^{19), 20)}$ from coke deposition on their surfaces. Actually, in the present work, the weight of the catalyst increased during the reaction. The amount of increase corresponded to about $7 \%$ of the weight of D.P.B.E fed at $20 \times 10^{4}$ g-catalyst $\times$ sec $/ \mathrm{g}$-molfeed. Since the formation of coke is associated with the formation of low boiling-point products ${ }^{21}$,

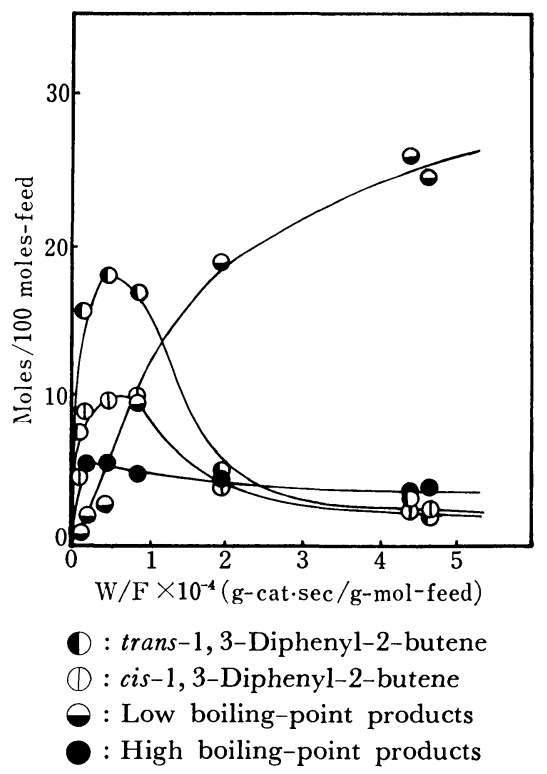

Fig. 5 Plots of Yields of Reaction Products vs. Contact Time over IS Catalyst

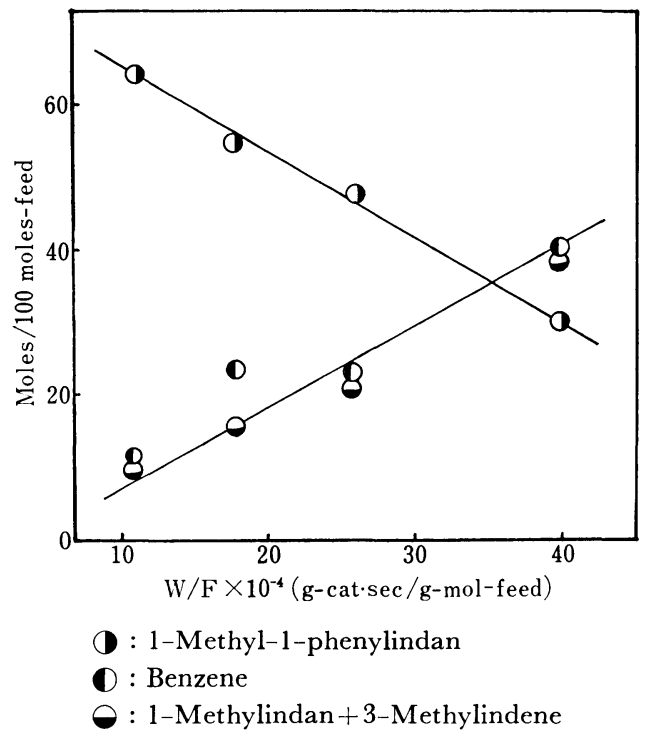

Fig. 6 Effect of Contact Time on Yields of 1-Methyl1-phenylindan and Low Boiling-Point Products over IS Catalyst

it could be anticipated that the formation of coke would be conspicuous at the earlier stages of the reaction, as can be seen from Fig. 3 .

Further, the effect of contact time on yield of each product over the IS catalyst is shown in Figs. 4, 5 and 6. In Fig. 4, the unconverted quantity of D.P.B.E decreased to a constant level at about 5 moles/100 moles-feed while the yield of 1-methyl-1-phenylindan increased up to a constant level at about 70 moles/100 moles-feed. With increasing contact time, the yields of cis- and trans- 
1,3-diphenyl-2-butenes attained their maximum values at 9 and 15 moles/100 moles-feed at $0.5 \times$ $10^{4}$ g-catalyst $\times$ sec/g-mole-feed, respectively, and then they decreased, as can be seen from Fig. 5. The formation of low boiling-point products increased gradually with increase in contact time, however, the formation of high boiling-point products was about 5 moles/100 moles-feed and constant. In Fig. 6, the decrease in the amount of 1-methyl-1-phenylindan formed was roughly equal to the increase in the amount of benzene or the sum of 1-methylindan and 3-methylindene formed. These results suggested that elimination of benzene from 1-methyl-1-phenylindan resulted in the formation of 1-methylindan and 3-methylindene.

\subsection{Relationships between Acidic Properties of Catalysts and Reaction Products}

The main products formed over the two catalysts were different; namely, 1-methyl-1-phenylindan was formed only over the IS catalyst, while 1,3-diphenyl-2-butenes were formed over both the IS and Neobead-P catalysts. The former was formed by isomerization of D.P.B.E to a cyclic compound and the latter was formed by the double-bond isomerization of D.P.B.E. It is considered that the difference in the main products formed over the two catalysts is attributable to the acidic properties of the catalysts. As shown in Fig. 1, Neobead-P catalyst contained only acid sites of $\mathrm{H}_{0}>+1.5$ while IS catalyst had a broad distribution of acid strengths compared with that of Neobead-P catalyst. The formation of 1-methyl1-phenylindan would be explained as taking place over the acid sites of $\mathrm{H}_{0}<+1.5$, which would be considered as Brönsted acid sites, because 1methyl-1-phenylindan was not formed over the Neobead-P catalyst. Therefore, it is suggested that 1-methyl-1-phenylindan be formed selectively over the acid sites of $\mathrm{H}_{0}<+1.5$ while 1,3-diphenyl-2butenes are formed mainly over the acid sites of $\mathrm{H}_{0}>+1.5$.

\subsection{Mechanism}

Both the Brönsted and Lewis acid sites exist on the surfaces of silica-alumina catalysts. It have been reported that, in general, with a decrease in alumina content of silica-alumina, the Lewis acidity decreases ${ }^{13)}$,23). The Lewis acidity of the IS catalyst here used is considered to be smaller than that of the Neobead-P catalyst. Consequently, it would be speculated that over the IS catalyst the proton addition either to the $\alpha$-olefin or the two phenyl groups in D.P.B.E by Brönsted acid sites precedes rather than hydride ion abstraction from D.P.B.E by Lewis acid sites. Further, any products which would be formed by proton addition to the phenyl groups of D.P.B.E would not be observed in the present work; moreover, the yields of low boiling-point products would be very small, as can be seen in Table 2. Thus, the first step in the reaction over the IS catalyst would be the proton addition to the $\alpha$-olefin in D.P.B.E (Eq. (1)).

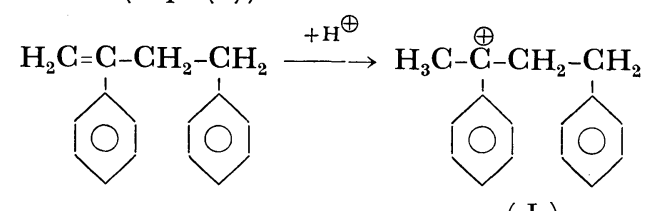

( I )

The tertiary benzyl carbonium ion I formed would be stabilized by such several terminations as proton elimination, aromatic substitution and hydride ion attachment.

The formation of 1,3-diphenylbutane though but slight was confirmed by GC-MS. The yield of 1,3-diphenyl-1-butene over the IS catalyst was less than about 2 moles/100 moles-feed, and the presence of 1-methyl-3-phenylindan could not be observed. Thus, the intramolecular hydride ion transfer reaction leading to the secondary benzyl carbonium ion II from the tertiary benzyl carbonium ion I would be disregarded. Consequently, the tertiary benzyl carbonium ion I should be the most important intermediate.

As shown in Eq. (7), the tertiary benzyl carbonium ion I can also be formed from 1,3-diphenyl2-butene.

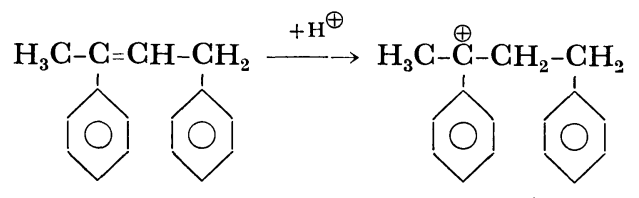

\section{( I )}

Hence, Eq. (7) represents the opposite reaction to that of Eq. (4), and Eq. (5) represents the opposite reaction to that of Eq. (1). Therefore, these reactions would be represented by Eq. (8).

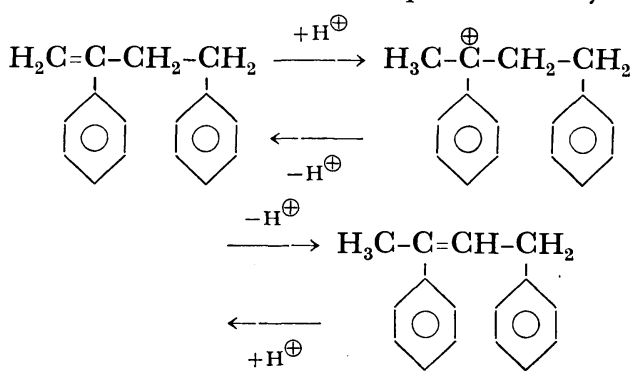

Here, the authors have confirmed by other experiments that 1,3-diphenyl-2-butenes were formed 


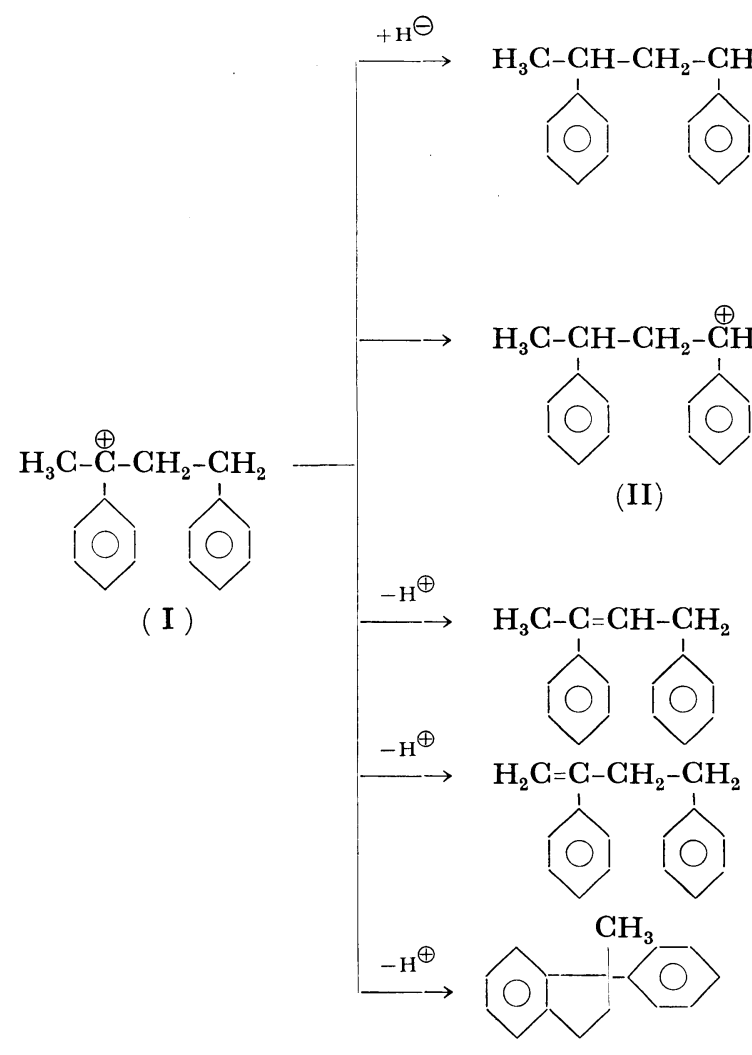

with high yields from D.P.B.E in the presence of a typical Brönsted acid such as sulfuric acidfootnote 1), where the cis/trans ratio was very small.

It was reported the rate of back isomerization of 1,3-diphenyl-2-butenes to D.P.B.E was very slow in comparison with that of the forward reaction ${ }^{22), 23)}$.

The reaction of Eq. (6) results in the formation of 1-methyl-1-phenylindan. A large amount of 1methyl-1-phenylindan was formed only over the IS catalyst (Table 2). Also, it was clear by comparison of the results obtained over both catalysts, IS and Neobead-P, that strong acid sites of $\mathrm{H}_{0}<$ +1.5 were effective in the formation of 1 -methyl1-phenylindan. Consequently, the intramolecular interaction between positive charge (tertiary benzyl carbonium ion) and $\beta$-phenyl ring seems to be an important factor in the reaction, where the $\beta$-phenyl ring stabilizes the positive charge ${ }^{24), 25)}$.

Over the IS catalyst, the double-bond isomerization of D.P.B.E and isomerization of D.P.B.E to 1-methyl-1-phenylindan took place competitavely in the region of 0 to $0.2 \times 10^{4} \mathrm{~g}$-catalyst $\cdot \mathrm{sec} / \mathrm{g}$-molfeed, and the total yield of 1,3-diphenyl-2-butenes was larger than that of 1-methyl-1-phenylindan under these conditions. However, with increasing

footnote 1) The cis/trans ratio of 1,3-diphenyl-2-butenes was 0.03 under the following conditions: reaction temperature, $70 \sim 90^{\circ} \mathrm{C}$; reaction time, $25 \sim 300$ min. contact time, the formations of cis- and trans-1,3diphenyl-2-butenes decreased, after passing through maxima, while the yields of 1-methyl-1-phenylindan and low boiling-point products increased gradually (Figs. 4 and 5). Further, in the range of $10 \times$ $10^{4}$ to $40 \times 10^{4} \mathrm{~g}$-catalyst $\cdot \mathrm{sec} / \mathrm{g}$-mol-feed, the increase in the yield of benzene or the sum of the yields of 1-methylindan and 3-methylindene was accompanied by decrease in the yield of 1-methyl1-phenylindan, and the formation of 1,3-diphenyl2-butenes was very slight (Fig. 6). From these results, it would be estimated that part of trans1,3-diphenyl-2-butenes formed was converted consecutively to 1-methyl-1-phenylindan and to low boiling-point products.

Over the Neobead-P catalyst, product distribution was simple and 1-methyl-1-phenylindan was not formed (Table 2). The fact that there was no formation of 1-methyl-1-phenylindan over the catalyst supports the consideration that it would be formed over the strong Brönsted acid sites. The fact that the large amount of 1,3-diphenyl-2butenes formed seems to be attributable to the weak acid strength of the Neobead-P catalyst, and to be indicative of the fact, that the catalyst would have no ability to promote fused ring formation of the intermediate I (Eq. (6)).

The formation of 1,3-diphenyl-1-butene over the Neobead-P catalyst was small but larger than that 


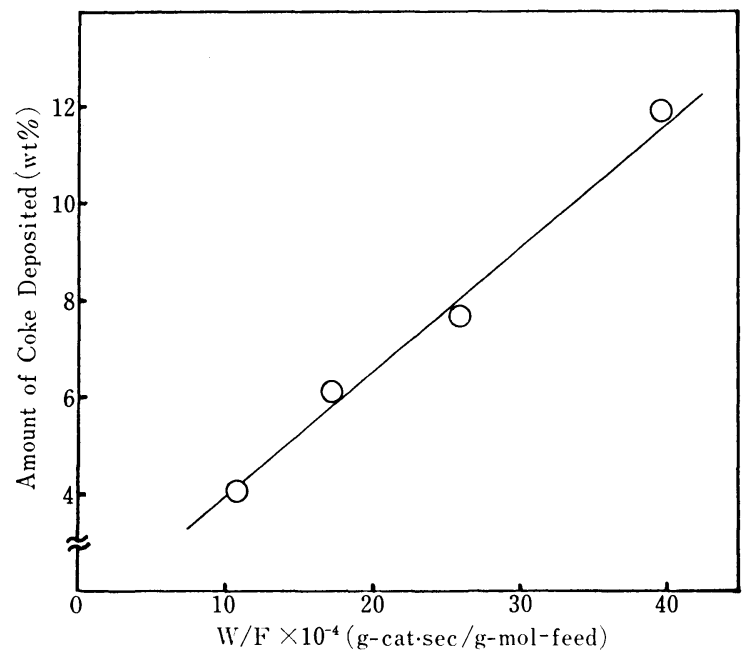

Fig. 7 Relationship between the Amount of Coke Deposited and Contact Time over IS Catalyst

over the IS catalyst. The presence of 1,3-diphenylbutane in the reaction products was confirmed by GC-MS. Also, the Lewis acidity of the Neobead-P was estimated to be larger than that of the IS catalyst as described earlier. Consequently, the possibility that 1,3-diphenyl-1-butene was formed by the interaction of Lewis acid sites and 1,3-diphenylbutane would be considered. However, the details are not available at the present stage.

Finally, the amount of coke deposited increased with increasing contact time as shown in Fig. 7. In the range of contact time, the decomposition of 1-methyl-1-phenylindan was promoted with increasing contact time (Fig. 6). From the results, it is suggested that the coke be mainly formed in the course of the formation of low boiling-point products from 1-methyl-1-phenylindan.

\section{Acknowledgment}

The authors wish to thank Mr. Okimori, Mr. Tanaka and Mr. Fujiwara for their assistance throughout the present experimental work and to express their gratitudes to Dr. Takido for NMR measurements of reaction products.

\section{References}

1) Ichikawa, M., Ando, H., J. Japan Petrol. Inst., 18 (7), 559 (1975).

2) Nishizaki, H., Ise, T., Netsu Kanri and Kougai, 26, (7), 33 (1974).

3) Tsusansho (通産省), Shigen Saisei Riyo Gijutsu Shisutem Kaihatsu Iinkai Hokoku (盗源再生利用技術 システム開発委員会報告)，(1972-1978).

4) Saeki, K., J. Japan Petrol. Inst., 17, (8), 24 (1974).

5) Sekiguchi, Y., Kuroki, T., Sawaguchi, T., Ikemura, T., Nippon Kagaku Kaishi, 1977, 1220.

6) Sekiguchi, Y., Ogawa, T., Kuroki, T., Ikemura, T., Kobunshi Ronbunshu, 35, (9), 581 (1978).

7) Spoerri, P. E., Rosen, M. J., J. Am. Chem. Soc., 72, 4918 (1950).

8) Corson, B. B., Dorsky, J., Nickels, J. E., Kurtz, W. M., Thayer, H. I., J. Org. Chem., 19, 17 (1954).

9) Mayo, F. R., J. Am. Chem. Soc., 90, 1289 (1968).

10) Fujita, M., Junkatsu, 18, (12), 45 (1973).

11) Trippett, S., "Advances in Organic Chemistry", Vol. 1, 83 (1960), Interscience, New York, N. Y.

12) Ogawa, T., Kuroki, T., Ikemura, T., Nippon Kagaku Kaishi, 1980, 754.

13) Tanabe, K., Takeshita， T., (田部浩三，竹下常一), “San Enki Shokubai (酸塩基触媒)", 159 (1966), Sangyo Tosho (産業図書).

14) Juge, F. E., Fry, A., J. Org. Chem., 35, (6), 1876 (1970).

15) Entel, J., Ruof, G. H., Howard, H. C., Anal. Chem., 25, 1303 (1953).

16) Parkhurst, R. M., Rodin, J. O., Silverstein, R. M., J. Org. Chem., 28, 120 (1963).

17) Swaguchi, T., Kuroki, T., Isono, T., Ikebayashi, N., Ikemura, T., Nippon Kagaku Kaishi, 1977, 1056.

18) Higashimura, T., Nishii, H., J. Polymer Sci : polymer chemical Edi., 15, 329 (1977).

19) Kunugi, T., Fujimoto, K., Sakai, T., J. Japan Petrol. Inst., 11, (9), 696 (1968).

20) Kunugi, T., Fujimoto, K., Sakai, T., J. Japan Petrol. Inst., 11, (2), 103 (1968).

21) Shokubai Gatsukai (触媒学会), “Shokubai Hanno (2) (触媒反応 (2))”, 245 (1973), Chigin Shokan（地人 書館).

22) Ela, S. W., Cram, D. J., J. Am. Chem. Soc., 88, 5777 (1966).

23) Germain, J. E., “Tankasuiso no Setsushoku conversion (炭化水素の接触コンバージョン)”, 142 (1972), Shoko Do (昭晃堂).

24) Williams, J. F. A., Tetrahedron, 18, 1487 (1962).

25) Sanvet, J. P., Vairon, J. P., Sigwalt, P., J. Polymer Sci. : Symposium No. 52, 173 (1975). 
要 旨

\title{
シリカーアルミナ触媒上での 2,4-ジフェニル-1-ブテンの異性化
}

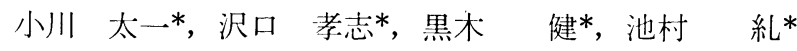

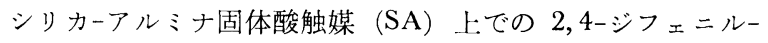
1-ブテン (DPBE) の異性化反応を調べるために, 固定床流通 系装置を用いて, 反応温度 $300^{\circ} \mathrm{C}$, 接触時間 $0.1 \times 10^{4} \sim 40 \times$ $10^{4} \mathrm{~g}$-cat $\times$ sec $/ \mathrm{g}$-mol-feed の条件下で実験を行った。反応に は2 種類の市販 SA 触媒 (IS と Neobead-P) を使用した。 両触媒を用いて実験したときの主要生成物はおのおの異なっ た（Table 2)。IS 触媒を用いた実験では 1-メチルー1-フェニ ルインダン, シスーとトランス-1,3-ジフェニル-2-ブテンそして 低沸点生成物が生成した (Fig. 4 と Fig. 5)。しかしながら， Neobead-P 触媒を用いた実験では主要生成物はシスーとトラ ンス-1,3-ジフェニル-2-ブテンのみであり,1-メチル-1-フェニ ルインダンと低沸点生成物は生成しなかった。 両触媒の全酸量 $(\mathrm{mmol} / \mathrm{g})$ の測定結果 (Fig. 1) 飞もとず

*日本大学理工学部工業化学科（101 千代田区神田酸河台 1-5)
いて，触媒の性質と反応生成物との関係を検討した結果，1-メ チルー1-フェニルインダンの生成（骨格異性化反応）は $\mathrm{H}_{\mathbf{0}}<+$ 1.5 の酸点上で起こり， $\mathrm{H}_{0}>+1.5$ の酸点上では DPBE の二 重結合異性化反応が選択的に起こることが明らかとなった。さ らに，IS 触媒では接触時間の増加によって，1-メチルー1-フェ ニルインダンの分解が促進され (Fig. 6)，同時にコーク生成 も顕著となった（Fig. 7)。このことは1-メチル-1-フェニルイ ンダンから低沸点生成物を生成する過程で，コークが生成する ことを示す。

本実験では IS 触媒に打いて，ブレンシュテッド酸点上での プロトン付加が DPBE のフェニル基よりも $\alpha$-オレフィンに 先行し (Eq.1)，第 3 級ベンジルカルボニウムイオン I は重要 な反応中間体であると推定された。一方，Neobead-P 触媒で

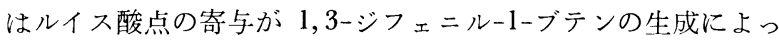
て推定された。

\section{Keywords}

2, 4-Diphenyl-1-butene, Isomerization, Silica-alumina, 1-Methyl-1-phenylindan, 1, 3-Diphenyl-2-butene 